\title{
Аналіз конкурентоспроможності кінноспортивних клубів в Україні
}

\author{
Наталія Шмаренкова
}

Національний університет фізичного виховання і спорту України, Київ, Україна

Анотація. Здійснено розробку методики та проведено аналіз рівня конкурентоспроможності кінноспортивних клубів в Україні. Мета. Розробка методичного забезпечення та аналіз рівня конкурентоспроможності кінноспортивних клубів в Україні. Методи. Експрес-аналіз, кількісний та якісний аналіз, статистичний та порівняльний методи. Результати. Встановлено, що дана методика заснована на використанні методу експрес-аналізу, методів кількісного та якісного аналізу, статистичного та порівняльного методу. Визначено, що по ложення методики передбачають здійснення чотирьох етапів оцінювання, її результатом $€$ визначення рівня конкурентоспроможності кінноспортивного клубу, який дорівнює сумі оціночних параметрів, скоригованих на вагові коефіцієнти. Представлене методичне забезпечення розраховане на оцінку конкурентоспроможності клубів, які надають комплекс кінноспортивних та супутніх послуг, мають розвинуту інфраструктуру, та клубів, які надають невеликий перелік кінноспортивних послуг. Доведено, що науковою новизною цієї розробки $€$ те, що вперше розроблено методику оцінювання рівня конкурентоспроможності кінноспортивних клубів з відповідним обґрунтуванням переліку оціночних параметрів (які враховують особливості діяльності суб'єктів даної сфери), їх вагових коефріцієнтів. На основі представленої авторської методики проведено аналіз рівня конкурентоспроможності кінноспортивних клубів в Україні, які надають комплекс кінноспортивних та супутніх послуг, мають розвинуту інфрраструктуру. Визначено основні характеристики

конкурентоспроможності, оцінено її параметри, виявлено ті кінноспортивні клуби, які зайняли найвищі місця в рейтингу за цим показником. Визначено основні переваги досліджуваних кінноспортивних клубів, що мали найбільший рівень конкурентоспроможності на сучасному етапі розвитку. В дослідженні відмічено, що авторська методика аналізу є універсальною, дозволяє визначити загальну картину конкурентоспроможності кінноспортивних клубів різних масштабів на основі незначного масиву вихідної інфрормації.

Ключові слова: конкурентоспроможність, кінноспортивний клуб, параметри, конкурентні переваги, інсрраструктура, послуги, тренування, верхова їзда.

\section{Natalia Shmarenkova}

\section{ANALYSIS OF THE COMPETITIVENESS OF HORSE RIDING CLUBS IN UKRAINE}

Abstract. The methodology was developed and the level of competitiveness of horse riding clubs in Ukraine was analyzed. Objective. Development of methodological support and analysis of the level of competitiveness of horse riding clubs in Ukraine. Methods. Express analysis, quantitative and qualitative analysis, statistical and comparative methods. Results. It is established that this methodology is based on the use of the method of express analysis, methods of quantitative and qualitative analysis, statistical and comparative method. It is determined that the provisions of the methodology envisage the implementation of four stages of evaluation, its result is to determine the level of competitiveness of the horse riding club, which is equal to the sum of evaluation parameters adjusted for weights. The presented methodological support is designed to assess the competitiveness of clubs that provide a range of equestrian and related services, have a developed infrastructure, and those that provide a small list of equestrian services. It is proved that the scientific novelty of this development is that for the first time a method of assessing the level of competitiveness of horse riding clubs with the appropriate substantiation of the list of evaluation parameters (which take into account the activities of entities in this field) of their weight coefficients. Based on the presented author's methodology, the analysis of the level of competitiveness of horse riding clubs in Ukraine, which provide a range of equestrian and related services, have a developed infrastructure was made. The main characteristics of competitiveness are determined, its parameters are estimated, those equestrian clubs which have taken the highest places in a ratingaccording to this index are revealed. The main advantages of the studied horse riding clubs, which had the highest level of competitiveness at the present stage of development,

Shmarenkova N. Analysis of the competitiveness of horse riding clubs in Ukraine. Theory and Methods of Physical education and sports. 2020; 4: 53-61 DOI: $10.32652 /$ tmfvs.2020.4.53-61
Шмаренкова Н. Аналіз конкурентоспроможності кінноспортивних клубів в Україні. Теорія і методика фрізичного виховання і спорту. 2020; 4: 53-61

DOI: $10.32652 /$ tmfvs.2020.4.53-61
Вступ. Конкурентоспроможність суб'єкта підприємництва виражається в його перевазі над іншими конкурентами, що входять до певного ринкового сегмента. Особливості оцінювання конкурентоспроможності підприємств кінноспортивної сфрери (кінноспортивних клубів) обумовлені певними характеристиками послуг та умовами фуннкціонування. Встановлення рівня конкурентоспроможності кінноспортивних клубів дозволяє оцінити фрактичний стан та проблеми за напрямом розподілу конкурентних позицій у рамках певних територій. Інформація про стан конкурентних позицій таких суб'єктів господарювання важлива для широкого кола користувачів: власників, конкурентів та клієнтів (існуючі та перспективні) та самого підприємства кінноспортивної сфери.

Відомості про стан конкурентоспроможності $€$ передумовою прийняття відповідних рішень, які стосуються як таких підприємств, так і перерахованого кола користувачів даних. А саме, власник (власники) може вирішити, що конкурентоспроможність низька і слід продати власну частку (або все підприємство), конкуренти отримують дані, які свідчать про те, наскільки краще або гірше функціонують аналогічні суб'єкти досліджуваної сфрери, існуючі клієнти можуть вирішити перейти до кінноспортивного клубу, який має більші конкурентні позиції, а може пересвідчитись, що обрав саме той клуб, нові клієнти мають можливість оцінити та обрати клуб, який є найбільш прийнятним за характеристиками, саме підприємство на основі аналізу отриманих даних приймає управлінські рішення про покращення рівня конкурентоспроможності. 3 огляду на зазначене, можемо відмітити важливість проблеми дослідження стану конкурентоспроможності кінноспортивних клубів в Україні.

Теоретико-методологічні, емпіричні питання вивчення конкурентоспроможності суб'єктів діяльності дослі- 
are determined. The study notes that the author's method of analysis is universal and allows determining the overall picture of the competitiveness of horse riding clubs of different scales on the basis of a small array of source information.

Keywords: competitiveness, horse riding club, parameters, competitive advantages, infrastructure services, training, horse riding.

джувались як вітчизняними, так і зарубіжними ученими, серед яких А. Кваско, А. Коротков, М. Карманов, А. Фліт, Г. Ветошко та ін. На сучасному етапі відсутні дослідження стану конкурентних позицій кінноспортивних клубів, також немає методичного забезпечення для здійснення такого дослідження. Зважаючи на важливість вивчення вказаної проблематики, створення методичного забезпечення та емпіричних даних дозволить закласти основу подальших наукових досліджень у даному напрямі.

Мета дослідження - розробка методичного забезпечення та аналіз рівня конкурентоспроможності кінноспортивних клубів в Україні.

Методи дослідження: експресаналіз, кількісний та якісний аналіз, статистичний та порівняльний методи.

Результати дослідження та їх обговорення. Систематизація наукових та методичних матеріалів дозволяє констатувати, що на сьогодні існують різні підходи до оцінювання конкурентоспроможності суб'єктів підприємництва.

У науковому дослідженні 0. Фліта зазначається, що основні методичні підходи до оцінювання конкурентоспроможності підприємств можна розподілити на дві групи: 1) які передбачають оцінювання конкурентоспроможності підприємницьких структур на основі фінансових показників їх діяльності; 2) засновані на оцінюванні конкурентних переваг суб'єкта господарювання як за допомогою якісних, так і шляхом використання кількісних методів та показників [10]. Можемо відмітити, що групування підходів до оцінювання даного напряму хоч і є досить узагальнюючим, але все ж охоплює основні положення методичного забезпечення вказаного аналізу.

Слід відмітити, що використання першої групи підходів потребує знань широкого спектра фрінансової інфрормації, існування фінансових да- них суб'єктів дослідження у відкритому доступі. Зауважимо, що вказаний підхід не підходить для використання аналізу стану конкурентоспроможності підприємств кінноспортивної сорери України через відсутність відкритих даних про фінансові звітності.

Зважаючи на це, заслуговує на увагу друга група підходів, яка об'єднує методи та показники, що дозволяють оцінити стан розвитку та діяльність цих суб'єктів за основними конкурентними перевагами. В складі методів та показників, що використовують у рамках цієї групи підходів, можна виділити:

- показник конкурентоспроможності, який розраховується як комплексне значення основних показників діяльності підприємства сфери 3 точки зору споживача (клієнта) [1]. Цей показник може бути розрахований із застосуванням методу SWOT-аналізу, через використання кожного оціночного фрактора діяльності підприємства (фракторний аналіз);

- параметричний показник конкурентоспроможності, що розраховується як сума параметричних показників діяльності підприємства, скоригованих на вагові показники [2] Слід констатувати, що використання параметричних показників передбачає можливість застосування методу кількісного аналізу [4];

- якісний показник конкурентоспроможності, що розраховується як сума якісних показників діяльност підприємства, скоригованих на вагові показники. Він може бути розрахований із застосуванням групи методів якісного аналізу, визначених експертним методом [4];

- кількісно-якісний показник конкурентоспроможності, що розраховується як сума кількісних та якісних показників діяльності підприємства скоригованих на вагові показники.

Потрібно відмітити, що стан конкурентоспроможності суб'єктів діяльності може вивчатись як на комп- лексному рівні із використанням всіх можливих показників та характеристик, так і на рівні екпрес-аналізу, в ході якого визначається загальна картина за вказаним напрямом. Методика, заснована на системі експресаналізу, дозволяє оцінити загальний стан, проблеми розвитку певного об'єкта дослідження за умов вивчення невеликого обсягу оціночних параметрів. У цьому випадку як об'єкт дослідження виступає конкурентоспроможність суб'єктів діяльності [8].

На основі вивчення положень наукових праць, керуючись даними про основні оціночні показники діяльності кінноспортивних клубів, нами було здійснено спробу розробити авторську методику оцінювання рівня конкурентоспроможності суб'єктів даної сорери. Вказана методика ґрунтується на використанні методу експрес-аналізу, методів кількісного та якісного аналізу, статистичного та порівняльного методу. На рисунку 1 представлено схему методики оцінювання рівня конкурентоспроможності кінноспортивних клубів.

Згідно із авторським підходом, передбачено здійснення чотирьох етапів оцінювання: перший - визначення кола кінноспортивних клубів (підприємств), які мають схожий рівень розвитку як суб'єктів дослідження; другий - встановлення оціночних параметрів рівня конкурентоспроможності кінноспортивних клубів; третій - встановлення вагових коефіцієнтів кожного з параметрів; четвертий - визначення рівня конкурентоспроможності кінноспортивних клубів (порівняльний аналіз), результатом чого $є$ визначення рівня конкурентоспроможності кінноспортивного клубу, який дорівнює сумі оціночних параметрів, скоригованих на вагові коефріцієнти.

Відповідно до положень авторської методики передбачено порядок оцінювання та межі критеріїв значень параметрів рівня конкурентоспроможності кінноспортивних клубів (табл. 1).

у складі таких коефріцієнтів для аналізу рівня конкурентоспроможності клубів, які надають комплекс кінноспортивних та супутніх послуг, мають розвинуту інфрраструктуру, про- 
1-й етап - визначення кола кінноспортивних клубів (підприємств), які мають схожий рівень розвитку як суб'єкти дослідження. Обирається перелік суб'єктів дослідження за параметрами обсягів діяльності: клуби, які пропонують невеликий перелік кінноспортивних послуг; клуби, які пропонують комплекс кінноспортивних та супутніх послуг, мають розвинуту інфраструктуру

$\downarrow$

2-й етап - встановлення оціночних параметрів рівня конкурентоспроможності кінноспортивних клубів.

Обираються найбільш вагомі параметри, які є найбільш значущими характеристиками під час вибору кінноспортивних клубів. Для дослідження рівня конкурентоспроможності клубів, які пропонують комплекс кінноспортивних та супутніх послуг, мають розвинуту інфраструктуру, можна використовувати такий перелік параметрів:

1) кількість кінноспортивних послуг, які пропонуються клубом;

2) відповідність параметрів ціна - якість на кінноспортивні послуги;

3) кількість супутніх додаткових послуг, які пропонуються клубом;

4) відповідність параметрів ціна - якість на кінноспортивні послуги;

5) рівень організації турнірів, престижність та масштабність турнірів;

6) рівень підготовки та професійності персоналу;

7) позитивний імідж клубу із надання кінноспортивних, супутніх послуг, організації турнірів;

8) укомплектованість кадрів та сформованість основної інфраструктури;

9) рівень інформативності та доступності даних про характеристики, склад, порядок надання послуг, цінові параметри;

10) рівень безпеки в клубі.

Для дослідження рівня конкурентоспроможності клубів, які пропонують невеликий перелік кінноспортивних послуг, можна використовувати такі параметри:

1) кількість кінноспортивних послуг, які пропонуються клубом;

2) відповідність параметрів ціна - якість на кінноспортивні послуги;

3) рівень організації турнірів, престижність та масштабність турнірів (якщо організовуються);

4) рівень підготовки та професійності персоналу;

5) позитивний імідж клубу із надання кінноспортивних послуг, організації турнірів;

6) укомплектованість кадрів та сформованість основної інфраструктури;

7) рівень інформативності та доступності даних про характеристики, склад, порядок надання послуг, цінові параметри;

8) рівень безпеки в клубі.

Оцінювання всіх параметрів здійснюється із застосуванням кількісно-якісного аналізу. Критерії кожного з параметрів наведено в таблиці 1

3-й етап - встановлення вагових коефіцієнтів кожного з параметрів.

Передбачено, що перелік сформовано за зменшенням значущості параметрів.

Вагові коефіцієнти для цих параметрів клубів, які:

- пропонують комплекс кінноспортивних та супутніх послуг, мають розвинуту інфраструктуру, можуть бути такими: для 1-го параметра - ваговий коефіцієнт становитиме 0,15, 2-го - 0,15, 3-го - 0,1, 4-го - 0,095, 5-го - 0,095, 6-го - 0,085, 7-го - 0,085, 8-го - 0,075, 9-го - 0,065;

- пропонують невеликий перелік кінноспортивних послуг можуть бути такими: для 1-го параметра - ваговий коефіцієнт 0,18, 2-го 0,18, 3-го - 0,15, 4-го - 0,14, 5-го - 0,1, 6-го - 0,1, 7-го - 0,075, 8-го - 0,075.

4-й етап - визначення рівня конкурентоспроможності кінноспортивних клубів, порівняльний аналіз.

Рівень конкурентоспроможності кінноспортивного клубу дорівнює сумі оціночних параметрів, скоригованих на вагові коефіцієнти. Високе значення показника становить: 0,75-1, середнє: 0,4-0,74; низьке: 0-0,39. Після отримання результатів за кожним клубом здійснюється порівняння на рівні досліджуваних суб'єктів

Рисунок 1 - Схема методики оцінювання рівня конкурентоспроможності кінноспортивних клубів (авторська розробка)

понується використовувати такий перелік параметрів: 1) кількість кінноспортивних послуг, які пропонуються клубом; 2) відповідність параметрів ціна-якість на кінноспортивні послуги; 3) кількість супутніх додаткових послуг, які пропонуються клубом; 4) відповідність параметрів ціна-якість на кінноспортивні послуги; 5) рівень організації турнірів, престижність та масштабність турнірів; 6) рівень підготовки та професійності персоналу; 7) імідж клубу з надання кінноспортивних, супутніх послуг, організації турнірів; 8) укомп- лектованість кадрів та сформованість основної інфрраструктури; 9) рівень інформативності та доступності даних про характеристики, склад, порядок надання послуг, цінові параметри; 10) рівень безпеки в клубі. Визначено, що до іншої категорії клубів, зокрема, тих, які надають невеликий перелік кінноспортивних послуг, можна застосовувати такий перелік параметрів: 1) кількість кінноспортивних послуг, які пропонуються клубом; 2) відповідність параметрів ціна-якість на кінноспортивні послуги; 3) рівень організації турнірів, престижність та масштабність турнірів (якщо організовуються); 4) рівень підготовки та професійності персоналу; 5) імідж клубу з надання кінноспортивних послуг, організації турнірів; 6) укомплектованість кадрів та ссрормованість основної інфраструктури; 7) рівень інфрормативності та доступності даних про характеристики, склад, порядок надання послуг, цінові параметри; 8) рівень безпеки в клубі.

У рамках авторської методики визначено порядок оцінювання та критерії цих параметрів, встановлено вагові коефріцієнти до кожного з них. Та- 
Т а б л и ц я 1. Порядок оцінювання та межі критеріїв значень параметрів рівня конкурентоспроможності кінноспортивних клубів (авторська розробка)

\begin{tabular}{|c|c|c|}
\hline Параметр & Критерій & Порядок оцінювання \\
\hline $\begin{array}{l}\text { Кількість кінноспортивних послуг, які } \\
\text { пропонуються клубом (Р1) }\end{array}$ & $\begin{array}{l}\text { Від } 1 \text { до } 3 \text { - оцінюється як 0,3, від } 3 \text { до } 5 \text { - як } \\
0,5 \text {, від } 5 \text { до } 10 \text { - як 0,75-1 }\end{array}$ & За даними сайтів клубів \\
\hline $\begin{array}{l}\text { Відповідність параметрів ціна-якість на } \\
\text { кінноспортивні послуги (Р2) }\end{array}$ & $\begin{array}{l}\text { Низька відповідність - оцінюється як 0,3, серед- } \\
\text { ня - як 0,5, висока - як 0,75-1 }\end{array}$ & $\begin{array}{l}\text { За даними експертної оцінки та резуль- } \\
\text { татами опитування клієнтів }\end{array}$ \\
\hline $\begin{array}{l}\text { Кількість супутніх додаткових послуг, які } \\
\text { пропонуються клубом (Р3) }\end{array}$ & $\begin{array}{l}\text { Від } 1 \text { до } 3 \text { - оцінюється як 0,3, від } 3 \text { до } 5 \text { - як } \\
0,5 \text {, від } 5 \text { до } 10 \text { - як 0,75-1 }\end{array}$ & За даними сайтів клубів \\
\hline $\begin{array}{l}\text { Відповідність параметрів ціна - якість на } \\
\text { кінноспортивні послуги (Р4) }\end{array}$ & $\begin{array}{l}\text { Низька відповідність - оцінюється як 0,3, серед- } \\
\text { ня - як 0,5, висока - як 0,75-1 }\end{array}$ & $\begin{array}{l}\text { За даними експертної оцінки та резуль- } \\
\text { татами опитування клієнтів }\end{array}$ \\
\hline $\begin{array}{l}\text { Рівень організації турнірів, престижність } \\
\text { та масштабність турнірів (P5) }\end{array}$ & $\begin{array}{l}\text { Низький рівень - оцінюється як 0,3, середній - } \\
\text { як 0,5, високий - як 0,75-1 }\end{array}$ & $\begin{array}{l}\text { За даними експертної оцінки, результа- } \\
\text { тами опитування фахівців, клієнтів, да- } \\
\text { ними оцінки аналітичних матеріалів }\end{array}$ \\
\hline $\begin{array}{l}\text { Рівень підготовки та професійності пер- } \\
\text { соналу (Р6) }\end{array}$ & $\begin{array}{l}\text { Низький рівень - оцінюється як 0,3, середній - } \\
\text { як 0,5, високий - як 0,75-1 }\end{array}$ & $\begin{array}{l}\text { За даними експертної оцінки, результа- } \\
\text { тами опитування фахівців, клієнтів, да- } \\
\text { ними оцінки аналітичних матеріалів }\end{array}$ \\
\hline $\begin{array}{l}\text { І̇мідж клубу щодо надання } \\
\text { кінноспортивних, супутніх послуг, } \\
\text { організації турнірів (P7) }\end{array}$ & $\begin{array}{l}\text { Поганий - оцінюється як 0,3, середній - як 0,5, } \\
\text { позитивний - як 0,75-1 }\end{array}$ & $\begin{array}{l}\text { За даними експертної оцінки, результа- } \\
\text { тами опитування фахівців, клієнтів, да- } \\
\text { ними оцінки аналітичних матеріалів }\end{array}$ \\
\hline $\begin{array}{l}\text { Укомплектованість кадрів та } \\
\text { сформованість основної інфраструктури } \\
\text { (P8) }\end{array}$ & $\begin{array}{l}\text { Низький рівень - оцінюється як 0,3, середній - } \\
\text { як 0,5, високий - як 0,75-1 }\end{array}$ & $\begin{array}{l}\text { За даними експертної оцінки, результа- } \\
\text { тами опитування фахівців, клієнтів, да- } \\
\text { ними оцінки аналітичних матеріалів }\end{array}$ \\
\hline $\begin{array}{l}\text { Рівень інформативності та доступності } \\
\text { даних щодо характеристик, скла- } \\
\text { ду, порядку надання послуг, цінових } \\
\text { параметрів (P9) }\end{array}$ & $\begin{array}{l}\text { Низький рівень - оцінюється як 0,3, середній - } \\
\text { як 0,5, високий - як 0,75-1 }\end{array}$ & $\begin{array}{l}\text { За даними експертної оцінки, результа- } \\
\text { тами опитування фахівців, клієнтів, да- } \\
\text { ними матеріалів сайтів клубів }\end{array}$ \\
\hline Рівень безпеки в клубі (Р10) & $\begin{array}{l}\text { Низький рівень - оцінюється як 0,3, середній - } \\
\text { як 0,5, високий - як 0,75-1 }\end{array}$ & $\begin{array}{l}\text { За даними експертної оцінки, результа- } \\
\text { тами опитування фахівців, клієнтів, да- } \\
\text { ними матеріалів сайтів клубів }\end{array}$ \\
\hline
\end{tabular}

кож визначено критерії оцінювання загального рівня конкурентоспроможності кінноспортивних клубів. Наукова новизна представленої розробки полягає в тому, що вперше розроблено методику оцінювання рівня конкурентоспроможності кінноспортивних клубів з відповідним обґрунтуванням переліку оціночних параметрів (які враховують особливості діяльності суб'єктів даної сфрери), їх вагових коефіцієнтів.

На основі розглянутої методики проведемо аналіз рівня конкурентоспроможності кінноспортивних клубів в Україні. За досліджувані суб'єкти обрано категорію клубів, які надають комплекс кінноспортивних та супутніх послуг, мають розвинуту інсрраструктуру. Серед них обрано такі: Дитяча школа верхової їзди «Конюшня Бутенко» (с. Проців, Київська обл.), Кінно- спортивний клуб «Equides» (Київська обл., с. Лісники), Кінноспортивний комплекс «Parade Allure» (Черкаська обл., м. Жашків), Кінноспортивний комплекс «Магнат» (Київська обл. c. Чубинське), Сімейний кінний клуб «DERGACHOV» (Київська обл., Обухівський р-н, с. Верем'я) [3, 5-7, 9].

У таблиці 2 представлено визначення рівня конкурентоспроможності Дитячої школи верхової їзди «Конюшня Бутенко» (с. Проців, Київська обл.). У ході дослідження встановлено, що Дитяча школа верхової їзди «Конюшня Бутенко» має високий рівень конкурентоспроможності - 0,801. Такий показник був пов'язаний 3 найбільш суттєвим впливом високих значень оціночних параметрів кількості кінноспортивних послуг, які пропонуються клубом, та параметра відповідності ціни та якості цих послуг (1-й та 2-й параметри), високим рівнем організації турнірів, престижністю та масштабністю турнірів (5-й параметр). Ця школа пропонує широкий спектр основних кінноспортивних послуг, які представлені послугами тренування, катання та пансіону для коней. Встановлено, що їх якість відповідає ціновим параметрам. Визначено, що значення інших оціночних параметрів також характеризується високими, але меншими значеннями.

у таблиці 3 наведено визначення рівня конкурентоспроможності Кінноспортивного клубу «Equides» (Київська обл., с. Лісники). За результатами розрахунків було встановлено рівень конкурентоспроможності на рівні 0,777. Це формально високе значення, але воно близьке до середнього $(0,74)$. Найвищі значення показника пов'язані 3 : 
Т а б л и ц я 2. Рівень конкурентоспроможності Дитячої школи верхової їзди «Конюшня Бутенко» станом на 30.09.2019 р.

\begin{tabular}{|c|c|c|c|c|}
\hline Параметр & Характеристика & $\begin{array}{l}\text { 3начення пара- } \\
\text { метра }\end{array}$ & $\begin{array}{c}\text { Ваговий } \\
\text { коефіцієнт }\end{array}$ & $\begin{array}{l}\text { Скориговане на ваговий } \\
\text { коефріцівнт значення па- } \\
\text { раметра (ст. } 4 \text { * ст. 5) }\end{array}$ \\
\hline $\begin{array}{l}\text { Кількість кінноспортивних послуг, які } \\
\text { пропонуються клубом (P1) }\end{array}$ & $\begin{array}{l}6 \text { основних послуг тренування, } 1 \\
\text { послуга катання, } 2 \text { послуги (паке- } \\
\text { ти) пансіону для коней }\end{array}$ & 0,9 & 0,15 & 0,135 \\
\hline $\begin{array}{l}\text { Відповідність параметрів ціна-якість } \\
\text { на кінноспортивні послуги (Р2) }\end{array}$ & Висока & 0,75 & 0,15 & 0,113 \\
\hline $\begin{array}{l}\text { Кількість супутніх додаткових послуг, } \\
\text { які пропонуються клубом (Р3) }\end{array}$ & 8 додаткових послуг & 0,8 & 0,1 & 0,080 \\
\hline $\begin{array}{l}\text { Відповідність параметрів ціна-якість } \\
\text { на кінноспортивні послуги (Р4) }\end{array}$ & Висока & 0,75 & 0,1 & 0,075 \\
\hline $\begin{array}{l}\text { Рівень організації турнірів, } \\
\text { престижність та масштабність } \\
\text { турнірів (P5) }\end{array}$ & Високий & 1 & 0,095 & 0,095 \\
\hline $\begin{array}{l}\text { Рівень підготовки та професійності } \\
\text { персоналу (Р6) }\end{array}$ & Високий & 0,75 & 0,095 & 0,071 \\
\hline $\begin{array}{l}\text { І̇мідж клубу з надання } \\
\text { кінноспортивних, супутніх послуг, } \\
\text { організації турнірів (P7) }\end{array}$ & Позитивний & 0,75 & 0,085 & 0,064 \\
\hline $\begin{array}{l}\text { Укомплектованість кадрів } \\
\text { та сформованість основної } \\
\text { інфраструктури (Р8) }\end{array}$ & Висока & 0,75 & 0,085 & 0,064 \\
\hline $\begin{array}{l}\text { Рівень інформативності та } \\
\text { доступності даних про характери- } \\
\text { стики, склад, порядок надання по- } \\
\text { слуг, цінові параметри (P9) }\end{array}$ & Висока & 0,75 & 0,075 & 0,056 \\
\hline Рівень безпеки в клубі (Р10) & Високий & 0,75 & 0,065 & 0,049 \\
\hline Загальний рівень (сума p.1-p.10) & & & & 0,801 \\
\hline
\end{tabular}

Примітка. Розраховано за даними [3], результатами опитування клієнтів, даними експертної оцінки

Т а б л и ц я 3. Рівень конкурентоспроможності Кінноспортивного клубу «Еquides» станом на 30.09.2019 p.

\begin{tabular}{|c|c|c|c|c|}
\hline Параметр & Характеристика & $\begin{array}{l}\text { Значення } \\
\text { параме- } \\
\text { тра }\end{array}$ & $\begin{array}{c}\text { Ваговий } \\
\text { коефіцієнт }\end{array}$ & $\begin{array}{l}\text { Скориговане } \\
\text { на ваговий коефріцівнт } \\
\text { значення параметра } \\
\text { (өт. } 4 \text { * ст. 5) }\end{array}$ \\
\hline $\begin{array}{l}\text { Кількість кінноспортивних послуг, } \\
\text { які пропонуються клубом (P1) }\end{array}$ & $\begin{array}{l}4 \text { основні послуги тренування, навчан- } \\
\text { ня, } 1 \text { послуга оренди клубних коней, } \\
1 \text { послуга (пакет) пансіону для коней }\end{array}$ & 0,75 & 0,15 & 0,113 \\
\hline $\begin{array}{l}\text { Відповідність параметрів ціна-якість } \\
\text { на кінноспортивні послуги (P2) }\end{array}$ & Висока & 0,75 & 0,15 & 0,113 \\
\hline $\begin{array}{l}\text { Кількість супутніх додаткових по- } \\
\text { слуг, які пропонуються клубом (Р3) }\end{array}$ & 10 додаткових послуг & 1 & 0,1 & 0,100 \\
\hline $\begin{array}{l}\text { Відповідність параметрів ціна-якість } \\
\text { на кінноспортивні послуги (P4) }\end{array}$ & Висока & 0,75 & 0,1 & 0,075 \\
\hline $\begin{array}{l}\text { Рівень організації турнірів, престиж- } \\
\text { ність та масштабність турнірів (Р5) }\end{array}$ & Високий & 1 & 0,095 & 0,095 \\
\hline $\begin{array}{l}\text { Рівень підготовки та професійності } \\
\text { персоналу (Р6) }\end{array}$ & Високий & 0,75 & 0,095 & 0,071 \\
\hline
\end{tabular}


Продовження таблиці 3

\begin{tabular}{|c|c|c|c|c|}
\hline Параметр & Характеристика & $\begin{array}{l}\text { 3начення } \\
\text { параме- } \\
\text { тра }\end{array}$ & $\begin{array}{c}\text { Ваговий } \\
\text { коефіцівнт }\end{array}$ & $\begin{array}{l}\text { Скориговане } \\
\text { на ваговий коеффіціент } \\
\text { значення параметра } \\
\text { (ст. } 4 \text { * ст. 5) }\end{array}$ \\
\hline $\begin{array}{l}\text { Імідж клубу з надання кінноспортив- } \\
\text { них, супутніх послуг, організації тур- } \\
\text { нірів (P7) }\end{array}$ & Позитивний & 0,75 & 0,085 & 0,064 \\
\hline $\begin{array}{l}\text { Укомплектованість кадрів та ссрор- } \\
\text { мованість основної інфрраструкту- } \\
\text { ри (Р8) }\end{array}$ & Висока & 0,75 & 0,085 & 0,064 \\
\hline $\begin{array}{l}\text { Рівень інформативності та доступ- } \\
\text { ності даних про характеристики, } \\
\text { склад, порядок надання послуг, ціно- } \\
\text { ві параметри (P9) }\end{array}$ & Середній & 0,5 & 0,075 & 0,038 \\
\hline Рівень безпеки в клубі (Р10) & Високий & 0,7 & 0,065 & 0,046 \\
\hline Загальний рівень (сума р.1-р.10) & & & & 0,777 \\
\hline
\end{tabular}

Примітка. Розраховано за даними [6], результатами опитування клієнтів, даними експертної оцінки

- високим значенням 1-го (кількість кінноспортивних послуг, які пропонуються клубом). А саме, клієнтам пропонується чотири основні послуги 3 тренування, навчання верхової їзди, одна послуга оренди клубних коней, одна послуга (пакет) пансіону для коней;

- 2-го (відповідність параметрів ціна-якість на кінноспортивні послуги). За результатами опитування, експертною оцінкою та думками фахівців встановлено, що клуб має досить високий рівень відповідності між якістю послуг даної категорії та ціновими параметрами. При цьому визначено, що ціни на послуги у Кінноспортивного клубу «Equides», як і у Дитячої школи верхової їзди «Конюшня Бутенко» високі;

- 3-го (кількість супутніх додаткових послуг, які пропонуються клубом). Відповідно до оцінки функціонування клубу визнано, що цим суб'єктом надається 10 додаткових послуг, які є додатковою перевагою для залучення клієнтів;

- 5-го (рівень організації турнірів, престижність та масштабність турнірів). Цей параметр також відіграє важливу роль у становленні конкурентних позицій клубу, визначено, що турніри, які організовуються «Equides», мають міжнародне та національне значення, $€$ престижними;

Значення інших параметрів також значне, але воно менше.

Згідно з результатами дослідження, можна констатувати, що Кінноспортивний комплекс «Parade Allure» (Черкаська обл., м. Жашків) має середню конкурентоспроможність $(0,738)$, значення якої наближається до високої (табл. 4). Найбільші значення конкурентоспроможності відмічено за параметром (P2), який характеризує відповідність ціна-якість на кінноспортивні послуги, кількість додаткових послуг, які $€$ додатковою перевагою для залучення клієнтів (Р3) (12 послуг). Цей клуб частково програє іншим тим, що не надає послуг тренування, а орієнтований більшою мірою на обслуговування власників коней Інші параметри розвитку клубу, які характеризують конкурентоспроможність, також мають суттєве значення.

У ході дослідження було встановлено високий рівень конкурентоспроможностіКінноспортивногокомплексу «Магнат» (Київська обл., с. ЧубинЇське) - 0,788. Таке значення забезпечене параметром кількості кінноспортивних послуг, які пропонуються клубом (P1) $(0,15)$, параметром відповідності ціни та якості кінноспортивних послуг (Р2) $(0,113)$, іншими високими значеннями. Як свідчать результати дослідження, найбільшою перевагою клубу $\epsilon$ кількість основних кінноспортивних послуг та їх якість, що відповідає ціні.

Як видно 3 таблиці 6, рівень конкурентоспроможності Сімейного кінного клубу «DERGACHOV» (Київська обл., Обухівський р-н, с. Верем'я) становить 0,813. Таке значення було забезпечене, переважно, параметром кількості кінноспортивних послуг, які пропонуються клубом (P1) $(0,15)(10$ послуг), параметром відповідності ціни та якості кінноспортивних послуг (Р2) $(0,113)$, параметром кількості супутніх додаткових послуг, які пропонуються клубом (Р3) $(0,10)$, іншими високими значеннями параметрів.

За даними порівняльного аналізу можна констатувати, що найбільший рівень конкурентоспроможності мають Сімейний кінний клуб «DERGACHOV» (значення 0,813) та Дитяча школа верхової їзди «Конюшня Бутенко» (значення 0,801). Перший у рейтингу є більш конкурентним через кількість, якість кінноспортивних послуг, кількість додаткових супутніх послуг, які залучають додаткових клієнтів. Дитяча школа верхової їзди «Конюшня Бутенко» досягла конкурентних пріоритетів через кількість та якість кінноспортивних послуг, високі 
Т а б л и ц я 4. Рівень конкурентоспроможності Кінноспортивного комплексу «Parade Allure» станом на 30.09.2019 р.

\begin{tabular}{|c|c|c|c|c|}
\hline Параметр & Характеристика & $\begin{array}{c}\text { Значення } \\
\text { параметра }\end{array}$ & $\begin{array}{c}\text { Ваговий } \\
\text { коеффіцієнт }\end{array}$ & $\begin{array}{l}\text { Скориговане на ваговий } \\
\text { коефіцієнт значення па- } \\
\text { раметра (ст. } 4 \text { * ст. 5) }\end{array}$ \\
\hline $\begin{array}{l}\text { Кількість кінноспортивних послуг, які про- } \\
\text { понуються клубом (Р1) }\end{array}$ & $\begin{array}{l}5 \text { основних послуг (оренда денни- } \\
\text { ка, послуги коваля, ветеринарного } \\
\text { лікаря, коняра, вершника) }\end{array}$ & 0,5 & 0,15 & 0,075 \\
\hline $\begin{array}{l}\text { Відповідність параметрів ціна-якість на } \\
\text { кінноспортивні послуги (Р2) }\end{array}$ & Висока & 0,75 & 0,15 & 0,113 \\
\hline $\begin{array}{l}\text { Кількість супутніх додаткових послуг, які } \\
\text { пропонуються клубом (Р3) }\end{array}$ & 12 додаткових послуг & 1 & 0,1 & 0,100 \\
\hline $\begin{array}{l}\text { Відповідність параметрів ціна-якість на } \\
\text { кінноспортивні послуги (Р4) }\end{array}$ & Висока & 0,75 & 0,1 & 0,075 \\
\hline $\begin{array}{l}\text { Рівень організації турнірів, престижність та } \\
\text { масштабність турнірів (P5) }\end{array}$ & Високий & 0,75 & 0,095 & 0,071 \\
\hline $\begin{array}{l}\text { Рівень підготовки та професійності персо- } \\
\text { налу (P6) }\end{array}$ & Високий & 0,75 & 0,095 & 0,071 \\
\hline $\begin{array}{l}\text { І̇мідж клубу з надання кінноспортивних, } \\
\text { супутніх послуг, організації турнірів (P7) }\end{array}$ & Позитивний & 0,75 & 0,085 & 0,064 \\
\hline $\begin{array}{l}\text { Укомплектованість кадрів та } \\
\text { сформованість основної інфраструктури } \\
\text { (Р8) }\end{array}$ & Висока & 0,75 & 0,085 & 0,064 \\
\hline $\begin{array}{l}\text { Рівень інформативності та доступності да- } \\
\text { них про характеристики, склад, порядок } \\
\text { надання послуг, цінові параметри (P9) }\end{array}$ & Високий & 0,75 & 0,075 & 0,056 \\
\hline Рівень безпеки в клубі (Р10) & Високий & 0,75 & 0,065 & 0,049 \\
\hline Загальний рівень (сума р.1-р.10) & & & & 0,738 \\
\hline
\end{tabular}

Примітка. Розраховано за даними [7], результатами опитування клієнтів, даними експертної оцінки

Т а б л и ц я 5. Рівень конкурентоспроможності Кінноспортивного комплексу «Магнат» станом на 30.09.2019 р.

\begin{tabular}{|c|c|c|c|c|}
\hline Параметр & Характеристика & $\begin{array}{c}\text { Значення } \\
\text { параме- } \\
\text { тра }\end{array}$ & $\begin{array}{l}\text { Ваговий } \\
\text { коеффіцієнт }\end{array}$ & $\begin{array}{c}\text { Скориговане на ваговий } \\
\text { коефіцієнт значення } \\
\text { параметра (ст. } 4 \text { * ст. 5) }\end{array}$ \\
\hline $\begin{array}{l}\text { Кількість кінноспортивних } \\
\text { послуг, які пропонуються } \\
\text { клубом (Р1) }\end{array}$ & $\begin{array}{l}12 \text { основних послуг (заняття верховою їздою), } \\
1 \text { послуга прокату амуніції, } 1 \text { послуга продажу } \\
\text { амуніції (магазин), } 2 \text { послуги підготовки та трену- } \\
\text { вання коней, } 1 \text { послуга ветеринарного лікаря, } 1 \\
\text { послуга утримання коней }\end{array}$ & 1 & 0,15 & 0,150 \\
\hline $\begin{array}{l}\text { Відповідність параметрів } \\
\text { ціна-якість на кінноспортивні } \\
\text { послуги (P2) }\end{array}$ & Висока & 0,75 & 0,15 & 0,113 \\
\hline $\begin{array}{l}\text { Кількість супутніх додатко- } \\
\text { вих послуг, які пропонуються } \\
\text { клубом (Р3) }\end{array}$ & 6 додаткових послуг & 0,75 & 0,1 & 0,075 \\
\hline $\begin{array}{l}\text { Відповідність параметрів } \\
\text { ціна-якість на кінноспортивні } \\
\text { послуги (P4) }\end{array}$ & Висока & 0,75 & 0,1 & 0,075 \\
\hline $\begin{array}{l}\text { Рівень організації } \\
\text { турнірів, престижність та } \\
\text { масштабність турнірів (P5) }\end{array}$ & Високий & 0,75 & 0,095 & 0,071 \\
\hline $\begin{array}{l}\text { Рівень підготовки та } \\
\text { професійності персона- } \\
\text { лу (Р6) }\end{array}$ & Високий & 0,75 & 0,095 & 0,071 \\
\hline
\end{tabular}


Продовження таблиці 5

\begin{tabular}{|c|c|c|c|c|}
\hline Параметр & Характеристика & $\begin{array}{c}\text { Значення } \\
\text { параме- } \\
\text { тра }\end{array}$ & $\begin{array}{c}\text { Ваговий } \\
\text { коефіцієнт }\end{array}$ & $\begin{array}{c}\text { Скориговане на ваговий } \\
\text { коефіцієнт значення } \\
\text { параметра (ст. } 4 \text { * ст. 5) }\end{array}$ \\
\hline $\begin{array}{l}\text { І̇мідж клубу з надання } \\
\text { кінноспортивних, супутніх послуг, } \\
\text { організації турнірів (Р7) }\end{array}$ & Позитивний & 0,75 & 0,085 & 0,064 \\
\hline $\begin{array}{l}\text { Укомплектованість кадрів } \\
\text { та сформованість основної } \\
\text { інфраструктури (P8) }\end{array}$ & Висока & 0,75 & 0,085 & 0,064 \\
\hline $\begin{array}{l}\text { Рівень інформативності та } \\
\text { доступності даних про характеристи- } \\
\text { ки, склад, порядок надання послуг, } \\
\text { цінові параметри (P9) }\end{array}$ & Високий & 0,75 & 0,075 & 0,056 \\
\hline Рівень безпеки в клубі (Р10) & Високий & 0,75 & 0,065 & 0,049 \\
\hline Загальний рівень (сума р.1-p.10) & & & & 0,788 \\
\hline
\end{tabular}

Примітка. Розраховано за даними [5], результатами опитування клієнтів, даними експертної оцінки

Т а б л и ц я 6. Рівень конкурентоспроможності Сімейного кінного клубу «DERGACHOV» (станом на 30.09.2019 р.

\begin{tabular}{|c|c|c|c|c|}
\hline Параметр & Характеристика & $\begin{array}{l}\text { Значення } \\
\text { параметра }\end{array}$ & $\begin{array}{l}\text { Ваговий } \\
\text { коеффіціснт }\end{array}$ & $\begin{array}{l}\text { Скориговане на ва- } \\
\text { говий коефріціянт } \\
\text { значення параметра } \\
\text { (ст. } 4 \text { * ст. 5) }\end{array}$ \\
\hline $\begin{array}{l}\text { Кількість кінноспортивних послуг, які } \\
\text { пропонуються клубом (P1) }\end{array}$ & $\begin{array}{l}6 \text { основних послуг (заняття верховою їздою, } \\
\text { тренування), } 1 \text { послуга прокату амуніції, меблів } \\
\text { та аксесуарів, } 1 \text { послуга ветеринарного лікаря, } \\
1 \text { послуги пансіону для коней, } 1 \text { послуга з про- } \\
\text { дажу коней }\end{array}$ & 1 & 0,15 & 0,150 \\
\hline $\begin{array}{l}\text { Відповідність параметрів ціна-якість на } \\
\text { кінноспортивні послуги (Р2) }\end{array}$ & Висока & 0,75 & 0,15 & 0,113 \\
\hline $\begin{array}{l}\text { Кількість супутніх додаткових послуг, } \\
\text { які пропонуються клубом (Р3) }\end{array}$ & 10 додаткових послуг & 1 & 0,1 & 0,100 \\
\hline $\begin{array}{l}\text { Відповідність параметрів ціна-якість на } \\
\text { кінноспортивні послуги (Р4) }\end{array}$ & Висока & 0,75 & 0,1 & 0,075 \\
\hline $\begin{array}{l}\text { Рівень організації турнірів, престиж- } \\
\text { ність та масштабність турнірів (Р5) }\end{array}$ & Високий & 0,75 & 0,095 & 0,071 \\
\hline $\begin{array}{l}\text { Рівень підготовки та професійності } \\
\text { персоналу (Р6) }\end{array}$ & Високий & 0,75 & 0,095 & 0,071 \\
\hline $\begin{array}{l}\text { І̇мідж клубу з надання кінноспортивних, } \\
\text { супутніх послуг, організації турнірів (P7) }\end{array}$ & Позитивний & 0,75 & 0,085 & 0,064 \\
\hline $\begin{array}{l}\text { Укомплектованість кадрів } \\
\text { та сформованість основної } \\
\text { інфраструктури (P8) }\end{array}$ & Висока & 0,75 & 0,085 & 0,064 \\
\hline $\begin{array}{l}\text { Рівень інформативності та доступності } \\
\text { даних про характеристики, склад, по- } \\
\text { рядок надання послуг, цінові параме- } \\
\text { три (P9) }\end{array}$ & Високий & 0,75 & 0,075 & 0,056 \\
\hline Рівень безпеки в клубі (Р10) & Високий & 0,75 & 0,065 & 0,049 \\
\hline \multicolumn{4}{|l|}{ Загальний рівень (сума p.1-p.10) } & 0,813 \\
\hline
\end{tabular}

Примітка. Розраховано за даними [9], результатами опитування клієнтів, даними експертної оцінки 
досягнення в організації турнірів, престижність та масштабність турнірів.

Висновки. Здійснено розробку методичного забезпечення та аналіз рівня конкурентоспроможності кінноспортивних клубів в Україні. Представлена методика оцінювання рівня конкурентоспроможності кінноспортивних клубів заснована на використанні методу екпрес-аналізу, методів кількісного та якісного аналізу, статистичного та порівняльного методу. Вона передбачає здійснення чотирьох етапів оцінювання, результатом чого є визначення рівня конкурентоспроможності кінноспортивного клубу, який дорівнює сумі оціночних параметрів, скоригованих на вагові коефіцієнти.

Методика розрахована на оцінювання конкурентоспроможності клубів, які надають комплекс кінноспортивних та супутніх послуг, мають розвинуту інсрраструктуру, та клубів, які надають невеликий перелік кінноспортивних послуг.

Визначено, що науковою новизною даної розробки є те, що вперше розроблено методику оцінювання рівня конкурентоспроможності кінноспортивних клубів з відповідним обґрунтуванням переліку оціночних параметрів (які враховують особливості діяльності суб'єктів даної сфрери), їх вагових коефіцієнтів. На основі авторської методики проведено аналіз рівня конкурентоспроможності кінноспортивних клубів в Україні, які надають комплекс кінноспортивних та супутніх послуг, мають розвинуту інфрраструктуру. Встановлено основні характеристики конкурентоспроможності, оцінено її параметри, виявлено ті клуби, які зайняли найвищі місця в рейтингу за даним показником.

У ході порівняльного аналізу визначено основні переваги досліджуваних кінноспортивних клубів, що мали найбільший рівень конкурентоспроможності на сучасному етапі розви- тку. Можна констатувати, що представлена методика аналізу є універсальною, дозволяє визначити загальну картину конкурентоспроможності кінноспортивних клубів різних масштабів на основі незначного масиву вихідної інфрормації.

Перспективи подальших досліджень передбачають вивчення стану сучасних кінноспортивних клубів, які зможуть забезпечити та створити нові аспекти та визначення додаткових оціночних показників стану конкурентоспроможності суб'єктів діяльності.

Конфлікт інтересів. Автор заявляє, що відсутній будь-який конфлікт інтересів.

\section{ЛІТЕРАТУРА}

1. Ветошко Г.В. Методические аспекть оценки конкурентоспособности фитнес-клубов на основе исследования факторов ее фрормирования. Азимут научных исследований: экономика и управление. 2018; 2(23): 89-92.

2. Воронов Д. Оценка и анализ конкурентоспособности предприятий. Дата оновлення: 23.10.2019. https://www.cfin.ru/management/ strategy/competit/analysis2.shtml (дата звернення: 23.10.2019).

3. Детская школа верховой езды «Конюшня Бутенко». Дата оновлення: 23.10.2019. http:// www.butenko-stable.com.ua/ (дата звернення 23.10.2019).

4. Кваско АВ. Аналіз методів оцінки конкурентоспроможності підприємства. Наукові записки. 2017; 1(54): 111-118.

5. Конноспортивный комплекс «Магнат». Дата оновлення: 23.10.2019. http://magnat.in.ua/ kompleks (дата звернення: 23.10.2019).

6. Конноспортивный клуб «Equides». Дата оновлення: 23.10.2019. https://equides com.ua/uroki-verhovoj-ezdy/ (дата звернення: 23.10.2019).

7. Конноспортивный комплекс «Parade Allure». Дата оновлення: 23.10.2019. http://paradeallure.com/ about/ (дата звернення: 23.10.2019).

\section{ІНФОРМАЦІЯ ПРО АВТОРА}

Шмаренкова Наталія koroleva1988@ukr.net

Національний університет фрізичного виховання і спорту України, 03150, Київ, вул. Фізкультури, 1

\section{INFORMATION ABOUT THE AUTHOR:}

Shmarenkova Natalya koroleva1988@ukr.net

National University of Ukraine on Physical Education and Sport, 03150, Kyiv, Fizkul'tury str., 1
8. Коротков АВ, Карманов МВ. Концептуальные основы исследования конкурентоспособности и инвестиционной привлекательности. Вестник УМО. 2011; 95: 51-55

9. Семейный конный клуб «DERGACHOV». Дата оновлення: 23.10.2019. http://dergachov. / (дата звернення: 23.10.2019)

10. Флит АЛ. Особенности оценки конкурентоспособности предприятия в сфере услуг Экономика и управление в сфрере услуг. 2014 12: $345-348$.

\section{LITERATURE}

1. Vetoshko GV. Methodical aspects of evaluating fitness club competitiveness through

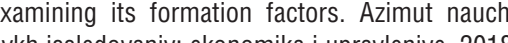
issledovaniy: ekonomika i upravleniye. 2018;

2. Voronov D. Assessment and analysis of enterprise competitiveness. Updated: 23.10 2019. https://www.cfin.ru/management/strategy/ competit/analysis2.shtml (accessed date: 23.10 (accessed date: 23.10.2019) enterprise competitiveness. Naukovi zay. $2017 ; 1(54): 111-118$.

«Magnat» Equestrian Center. Updated: 3.10.2019. http://magnat.in.ua/kompleks (accessed date: 23.10.2019).

6. «Equides» Equestrian Center. Updated: sed date: 23.10.2019) : 23.10.2019. http://paradeallure.com/about/ (23.10.2019).

Kotkov AV, Karmanov MV. Conceptur for studying competitiveness and investment attraction. Vestnik UM0. 2011; 95: 51-55.

"DERGACHOV» Family Equestrian Center. chetitiveness in service sphere. Ekonomika upravleniye v sfere uslug. 2014; 12: 345-348.

Надійшла 26.02.2020 